〈抄録〉第 25 回 日本臨床薬理学会年会 2004 年 9 月 17 18 日 静岡 シンポジウム 11 (安全性分野)：有害事象の評価に関するコンセンサスを目指して

\title{
4 。アレルギー起因薬物の同定試験の有用性と限界性
}

\author{
宇 野 勝 次*
}

$\beta$-ラクタム剤を中心とする注射用抗菌薬のショック の予知に皮内反忘は広く実施され、薬疹、薬阂性肝障害、 薬剤性肺炎などの起因薬剤検出に薬剤添加リンパ球刺激 試験（DLST）が汎用されてきた。しかし、日本化学療 法学会の提言を受けて厚生労衝省は 2004 年 9 月に注射 用抗菌薬の皮内反応の中止を公布し、近年原因薬物検出 におけるDLST の有効性に問題視する報告も少なくない。 このような状況下で、アレルギ一起因薬物同定試験の有 効性と限界性を検討することは副作用原因薬物の検索の 発展に寄与するものと考える。

\section{1. 薬物有害反応の臨床解析}

薬物による有害反応は、薬物自体が有している薬理作 用により誘発される中毒性副作用と薬物が抗原あるいは ハプテンとなり生体の抗体ないし感作リンパ球と反応し て誘発されるアレルギー性副作用に大別されるが、その 原因薬物の検索には両者とも臨床解析が重要である。臨 床解析の有用な要素は、異常症状と薬剤の時間的因果関 係、既存疾患の悪化の可能性、並びに服薬中止による症 状改善の有無である。すなわち、症状と薬剤の時間的因 果関係があり、既存疾患起因の可能性がなく、服薬中止 により症状が改善した場合は「おそらく関連性あり $(+)$ 小 症状と薬剤の時間的因果関係があり、既存疾患起因の否 定と服薬中止による症状改善のどちらか一方の条件が欠 落した場合は「たぶん可能性あり (土)」、症状と薬剤の 時間的因果関係がない場合は「たぶん可能性なし (一)」 に分類され、薬剤と症状との因果関係や被疑薬剤が推定 される。

さらに、被疑薬剤の再投与（チャレンジテスト）によ り副作用原因薬剤が確定される。しかし、チャレンジテ ストは患者のリスクが大き過ぎるため、中毒性副作用は 被疑薬剤の薬力学・薬物動態学 (薬物間相互作用も含む)

\footnotetext{
* 水原郷病院薬剤科

干 959-2093 阿賀野市岡山町 13-23
}

的検討、アレルギー性副作用はアレルギー起因薬物同定 試験を行い、起因薬物を検出し、薬物有害反応の発症メ カニズムを解析するが一般的である。

2. アレルギー起因薬物同定試験の種類

アレルギー起因薬物同定試験は、生体内（in vivo）と 生体外（in vitro）試験に大別される。in vivo試験では、 負荷試験（チャレンジテスト）と皮膚試験があり、皮膚 試験には皮内反応と貼付試験（パッチテスト）がある。 また、皮内反応の予備試験として择皮法（スクラッチテ スト）と単刺法（プリックテスト）がある。

in vitro 試験では、血清学的手段を用いた試験と免疫細 胞を用いた試験に分けることができる。血清学的試験に は薬威添加クームス試験、感作赤血球凝集試験、放射免 疫吸着試験、酵素結合免疫吸着測定法 (ELISA) などが あり、細胞性試験では、ヒスタミン遊離試験、細胞性抗 原刺激試験、DLST、マクロファージ遊走阻止試験、白 血球遊走試験 (LMT)、サイトカイン・ケモカイン測定、 サイトカイン mRNA 測定などがある。

\section{3. アレルギー起因薬物同定試験の有用性}

in vivo試験では、チャレンジテストは確実性が高いが、 前述の如くリスクが大き過ぎるという問題があり、さら に発症メカニズムも解明できず、陰性の場合は因果関係 の否定に必ずしも繋がらない欠点もある。皮膚試験では 皮内反応はアナフィラキシー反応の即時型過敏反応、パ ッチテストは遅延型過敏反応に用いられる。当施設（水 原郷病院）の 17 年間の $\beta$-ラクタム剂ショックを検討寸 ると、件数は 10 件ですべて内服剂であった。この結果は、 皮内反応陽性患者には注射用抗菌薬を使用しなかったこ とに起因し、皮内反応が $\beta$-ラクタム剂ショックのスクリ ーニングとして有用であることを示唆する。また、皮内 反応はある程度の危険も伴うため、ショック発現の危険 性が高い場合ではプリックテストから施行した方がよい と考える。パッチテストは当施設の成績では薬疹に対し て 10\%弱の陽性率で、患者の負担が大きい割には感度が 
低く、接触性皮膚炎を除いて有用性は低いと考えられる。 in vivo 試験では、当施設で同一薬剂過敏症疑診患者と 薬阂非過敏症患者を対象に数種類のアレルギー起因薬物 同定試験の比較検討を試みた。ショックを含まない皮疹 や肝障害を中心とした $\beta$-ラクタム剂過敏症疑診患者 90 例の陽性率（偽陽性率： $\beta$ ・ラクタ 剂非過敏症患者 30 例に対する $\beta$-ラクタム剂 3 剂の陽性率）は、皮内反応が $0 \%(0 \%)$ 、赤血球凝集試験が $7 \%(0 \%) 、 \mathrm{LMT}$ が $76 \%$ (4\%) で、LMTの $\beta$ ・ラクタム剂過敏症疑診患者におけ る陽性率が他試験および偽陽性を有意 $\left(\mathrm{P}<0.0001, \chi^{2-}\right.$ test）に上回った。また、 $\beta$-ラクタム剂過敏症疑診患者 89 例では ELISA の $8 \%$ に比べ LMT が $74 \%$ と有意（P

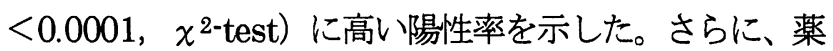
剂過敏症疑診患者 100 例（偽陽性率 : 薬剂非過敏症患者 90 例の 1 週間以上の服用薬剂に対する陽性率) では、 DLST が 20\%（7\%)、LMT が 61\%（7\%）の陽性率を 示し、両試験とも偽陽性を有意 (DLST; P $<0.02, \mathrm{LMT}$;

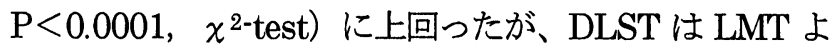

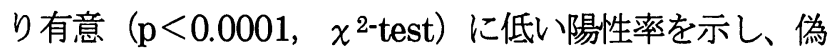
陽性との差がわずかで感度の点で限界性を示した。当施 設の 14 年間（1990 2003 年）の薬剤過敏症疑診患者 1,016 例における LMT は全体で $72 \%$ 、過敏症状別では 皮疹が $75 \%$ (症例数 : 651)、肝障害が $73 \%$ (255)、血 液障害が $78 \%$ （36）、消化管障害が $48 \%$ （29）、発熱（単 独）が $89 \%$ (28)、肺障害が $75 \%$ (28)、ショックが $65 \%$

（26）、腎障害が $64 \% （ 11 ）$ の陽性率を示し、アレルギ 一反応の関与が低い消化管障害を除いて各症状とも高い 陽性率を示した。したがって、LMTはアレルギ一起因薬 物同定試験として有用であると考えられる。

しかし、従来のLMT のアガロース平板法(LMT-plate) は手技が難しく、遊走用白血球の調製で多量の血液を必 要とする欠点がある。そこで、ケモタキスチャンバーを 利用した LMT-chamber を考案し検討を行った結果、薬 剂過敏症疑診患者 25 例では LMT-plate が $64 \%$ 、 LMT-chamber が $76 \%$ の陽性率を示し、さらに LMT-chamber は薬昘過敏症弱疑診（土）患者 25 例の $38 \%$ に比へ薬剂過敏症強疑診 (+) 患者 140 例には $86 \%$ と有意 $\left(\mathrm{P}<0.0001 ， x^{2-\text { test }}\right)$ に陽性率を示した。さら に、LMT-plate による白血球遊走促進因子検出群では $\mathrm{IL}-1 \alpha 、$ IL-1 $\beta$ 、IL-2 および TNF $\alpha$ の有意 $(\mathrm{P}<0.005$, t-test）に高い産生を認め、 $\beta$-ラクタム剂過敏症疑診患者 におけるLMT-plateによる白血球遊走阻止因子検出群で は IL-8 の有意（P<0.02， t-test）に高い産生を認めた。 したがって、LMT-chamber は LMT-plate より有用で であり、今後 LMT は LMT-chamber が推称され、さら
に将来サイトカイン測定によるアレルギー起因薬物同定 試験のケミカルアッセイが可能になると考えられる。

4. アレルギー起因薬物同定試験の限界性

アレルギー起因薬物同定試験の限界性は偽陰性と偽陽 性の存在である。約 $15 \%$ の薬剤と症状との因果関係 (土) を除いても、LMT は $15 \%$ 弱の偽陰性が存在することに なる。偽陰性の原因は、試験の技術的問題を除外すると 薬物の抗原形成、添加物によるアレルギーおよび偽薬剤 アレルギーがある。薬物の抗原形成では、薬剤の生体内 代謝産物が抗原性を示す場合が少なくなく、薬阂性肝障 害や光線過敏症にその例を見ることができる。添加物に よるアレルギーでは、添加物のパラオキシ安息香酸やポ リソルベートにLMT陽性を認めた事例から推察できる。 偽薬剂アレルギーはアレルギー様症状を発現するが、薬 剂が抗原としてではなく、薬剤自体が持つ薬理学的作用 により感受性の高い患者に誘発されるもので、アスピリ ン過敏症、リドカインショック、ACE 阻害薬による血管 浮腫など LMT 陰性例の約 $1 / 4$ に認めることができる。

偽陽性は、DLST やLMT で $10 \%$ 弱存在し、負荷試験 との相関ではもっと多くなると推測される。偽陽性の原 因には、薬物自体の免疫活性がある。小柴胡湯による間 質性肺炎の 3 割以上に DLST 陽性を根拠にしていたが、 小柴胡湯の $100 \mu \mathrm{g} / \mathrm{ml}$ 以上の濃度では DLST も LMT-plate も小柴胡湯非過敏症者 6 例全て陽性を示し、 小柴胡湯の構成成分である柴胡、甘草、黄芩にDLST お よび LMT 活性を示した。したがって、生薬の抗原性を 認めたのではなく、生薬自体の免疫活性を示したことに なる。さらに、偽陽性の原因には免疫反応と過敏症状の 相関の不明が根底にある。すなわち、阻止抗体や抑制性 $\mathrm{T}$ 細胞の存在とサイトカインなどの過敏症発現物質の閾 值である。抑制性 $\mathrm{T}$ 細胞の存在と過敏症発現物質の閾値 に関しては現在データを持っていないが、阻止抗体に関 しては、LMT 陽性患者 82 例について患者血清添加群と 無添加群で検討した結果、両群とも陽性が $7 \%$ 、血清添 加群のみ陽性が $65 \%$ 、血清無添加群のみ陽性は $26 \%$ を占 めた。血清無添加群のみに $26 \%$ 陽性を示した結果は、患 者血清中に薬剤と感作リンパ球との反応を阻止する特異 抗体が薬剤過敏症の約 $1 / 4$ に存在する可能性を示唆する。 この結果は、逆に負荷試験が陰性でも薬剤と過敏症状の 因果関係を必ずしも否定できないことを示唆する。

以上の検討から、アレルギー起因薬物同定試験はまだ 解決しなければならない問題が多くあり、これらの問題 を一つ一つ解明して行くことが副作用原因薬物の検索の 進歩に慗がると考える。 